\title{
THE NEW JERSEY COLLEGE FOR WOMEN: MIDDLE CLASS RESPECTABILITY AND PROTO-FEMINISM, 1911-1918
}

\author{
BY MARIE MARMO MULLANEY
}

Ms. Mullaney is a graduate student in history at Rutgers

HE assumption that progress and the higher education of
women have historically been two sides of the same coin has
come to be challenged by women's historians who have embarked on a closer investigation of exactly what American women were being educated for in the institutions of higher learning that became available to them throughout the nineteenth century. ${ }^{1}$ The aggressive careerism that was the hallmark of Bryn Mawr under the leadership of M. Carey Thomas is well-documented, ${ }^{2}$ but certainly not all women came to higher education afire with the same ideals. By r9ro, even at Bryn Mawr, a "wave of domestic complacency" had overcome students. The heyday of 'Thomas' firm control had passed, and with it, the sharply defined independent character of the "Bryn Mawr woman." As the twentieth century opened, women were demanding not the old classical education, but an education that would assure them of roles in the new vocational realms then opening up.

Nowhere is this change of focus better seen than in the movement to establish a college for women in New Jersey in the second decade of the twentieth century. The women reformers who led the fight in this state were adamant that women be educated so as to assume their "rightful" places in the "modern" world. The founders of the "New Jersey College for Women"-today, Douglass College, the women's division of Rutgers, the State University of New Jersey, and one of the few remaining public women's colleges in the United States-had a definite conviction of what women should accomplish with the educa-

1 See, for example, Jill K. Conway, "Perspectives on the History of Women's Education in the United States," History of Education Quarterly, XIV (1974), I-II.

${ }^{2}$ See Barbara M. Cross, ed., The Educated Woman in America: Selected Writings of Catharine Beecher, Margaret Fuller, and M. Carey Thomas (New York: Teachers College Press, 1965), pp. 1 37-175; Edith Finch, Carey Thomas of Bryn Mawr (New York: Harper and Bros., 1947); and Roberta Wein, "Women's Colleges and Domesticity, 1875-1918," History of Education Quarterly, XIV (1974), 31-47.

${ }^{3}$ Wein, 43-45. 
tion that they had been taught to prize so highly. The New Jersey campaign is highly instructive in challenging the assumption that women's access to higher education has in and of itself been a liberating experience. The aims of the college's founders serve as a good illustration of the narrowing of vision that came to plague the American women's movement as a whole in the period immediately preceding the achievement of suffrage. ${ }^{4}$ An analysis of the conservative, highly respectable ideology of college publicists provides one more example of the fatal paralysis of thought to which the death of American feminism after I 920 has been attributed. ${ }^{5}$

American women had been attaining the benefits of higher education since before the Civil War. ${ }^{6}$ Not only were private academies founded for this purpose, but a few colleges, such as Oberlin and Antioch, also opened their doors to women in the antebellum period. The great midwestern universities became coeducational after the War, while in the East, the hostility of the old elite male colleges to coeducation forced the establishment of private women's colleges, such as Bryn Mawr, modeled on the classical curricula of the elite male schools. A novel development in the East was the creation of so-called "coordinate" or "affiliated" colleges, linked to already existing male institutions. Radcliffe, for example, was formally chartered as the coordinate women's college of Harvard in 1893 , although it had been known informally as "Harvard Annex" since I882. Cheaper to fund and operate since such facilities as libraries and faculties could be shared with the parent institution, affiliated colleges were actually born in compromise with Trustees who refused to be moved on the subject of coeducation. Thus, by the beginning of the twentieth century, the number of American college educated women was growing rapidly. By I900, according to

${ }^{4}$ The primary source used for uncovering the ideology of the movement was the Roth Collection, the Mabel Smith Douglass Papers of the Mabel Smith Douglass Library, Douglass College, New Brunswick, N.J., hereinafter cited as RC-MSD. Other catalogued materials pertaining to the founding and early history of the New Jersey College for Women are also to be found in the library under the general headings of "N.J.C.-ana" and "Douglassensia."

${ }^{5}$ See William L. O'Neill, Everyone Was Brave: A History of Feminism in America (Chicago: Quadrangle Books, 1971).

${ }^{6}$ For a general discussion of the achievement of higher education by American women, see Lois Banner, Women in Modern America: A Brief History (New York: Harcourt, Brace, Jovanovich, Inc., I 974); Eleanor Flexner, Century of Struggle: The Woman's Rights Movement in the United States (New York: Atheneum, 1970); Mabel Newcomer, A Century of Higher Education for American Women (New York: Harper and Bros., 1959); and Thomas Woody, A History of Women's Education in the United States, 2 vols. (New York: Science Press, 1929). 
historian Arthur M. Schlesinger, $80 \%$ of colleges, universities, and professional schools admitted women. ${ }^{7}$

The state of New Jersey was decidedly behind this national trend in the movement for female higher education. It had no nondenominational female college, ${ }^{8}$ and existing all-male institutions refused to concede to coeducation. The only institutions of higher learning which the state provided for women were a system of normal schools, which fitted girls with a certificate to teach in the elementary grades only. Not only did this system of "higher education" immediately channel girls into the respectable profession of teaching, but it also relegated them to the lower rungs of the educational hierarchy. Since the State Board of Education mandated a college degree to teach in the high schools of the state, even high school teaching was effectively closed to all women who had neither the financial resources nor physical vitality to travel outside the state to obtain the required diploma.

By the early twentieth century, the injustice of this situation became apparent to reformers, both male and female, imbued with the Progressive spirit of the time. Women banded together in organizations such as the College Club of Jersey City, for the purpose of raising funds to provide scholarships for deserving girls to travel outside the state to pursue their education. It was recognized, however, that such small scale, compensatory efforts were far from being an efficient or effective solution to the problem, since statistics showed that by I9 I0, New Jersey high schools, on the average, were graduating one-and-one-half times the number of girls as boys. ${ }^{9}$ Although New Jersey's sons had Princeton, Rutgers, and Stevens to attend, its daughters were denied further educational options by their home state. The inequities of the New Jersey system, in the eyes of the reformers, were aggravated by the fact that Rutgers, as the land grant college for New Jersey, received both federal and state funds; furthermore, the state provided 70 full tuition scholarships annually to deserving Rutgers students.

Thus, the movement to establish a college for women in New Jersey

${ }^{7}$ A. M. Schlesinger, The Rise of the City, $187^{8-1898}$ (New York: Macmillan, I933), p. 205 .

${ }^{8}$ The College of Saint Elizabeth in Convent Station, founded in 1899 , served a limited Roman Catholic clientele.

3 "Free College Course for Your Girl?" N.J.S.F.W.C. pamphlet; and Robert W. Scoon, "The Need of a College for Women in New Jersey," pamphlet published under auspices of N.J.S.F.W.C., 1917; both in New Jersey State Federation of Women's Clubs, Scrapbook containing documents pertaining to the founding and early history of the College presented to N.J.C. on its 25 th anniversary, hereinafter cited as NJSFWC$\mathrm{SB}, \mathrm{NJC}$-ana. 
was initially grounded in the same "argument from justice" that underlay early suffrage ideology. ${ }^{10}$ New Jersey owed higher education, as a right, to its female citizens. Since New Jersey's neglect of its female population was heightened by the status of Rutgers, the tactics to be pursued by the reformers at first seemed clear: "the speedy admission of women into Rutgers College."'11

The campaign for college education for New Jersey women began in the fall of 19r 1 , with the presentation of this line of reasoning at a district meeting of the New Jersey State Federation of Women's Clubs, by the chairperson of the Federation's committee on education, Mrs. John V. Cowling. From the first, the college movement was created, molded, and led by the women of the N.J.S.F.W.C. The Federation sponsored lectures, pageants, publicity campaigns, and fund raising events to create support for the cause of a women's college. Under the auspices of the Woman's College Committee of the Federation, the women of the state came to be united in an elaborate organizational structure that formed a powerful pressure group for the college drive. ${ }^{12}$ As such, the type of college eventually created was imbued with the respectable, conservative, middle class ethos that typified the women of the N.J.S.F.W.C., and its parent body, the General Federation of Women's Clubs.

Leisured, middle class American women had been joining literary and cultural clubs since the mid-nineteenth century, for purposes of both comradeship and self-improvement. Such grass roots organizations not only served to alleviate the boredom of the middle class housewife, but also enabled women of common background and breeding to work

${ }^{10}$ The term "argument from justice" as applied to suffrage ideology was developed by Aileen S. Kraditor, and collectively refers to all arguments for suffrage based on ideas of justice, natural rights, and consent of the governed. Women ought to have political rights, the argument went, because justice required it. See The Ideas of the Woman Suffrage Movement I890-19zo (Garden City, N.Y.: Doubleday and Co., Inc., 1971), p. 58.

${ }_{11}$ Mabel Smith Douglass, "The Early History of N.J.C.: Personal Recollections by Dean Douglass," pamphlet reprinted from the 1929 Quair, The Student Annual, p. 5; NJC-ana.

${ }^{12}$ See Bulletin published by Woman's College Committee of N.J.S.F.W.C., Feb.Mar., I915, RC-MSD, Box II, folder i7; "Free College Course for Your Girl?", "Wanted! A State College for New Jersey Women," and "N.J.S.F.W.C. Plan for Distribution of Loan Scholarships," NJSFWC-SB; and "Beautiful Pageant Given by College Women's Club in Weequahic Park Yesterday," The Sunday Call, Newark, June I4, IgI4. Beneath the state chairperson and co-operating chairperson of the Woman's College Committee of the Federation were to be found district vice-presidents and city chairpersons, and a small committee in each city of each district to report directly to the district vice-president. 
together in philanthropic and community projects. The General Federation of Women's Clubs, founded in I 890 , was a sprawling, superstructural organization that attempted to give form, direction, and focus to the hundreds of these clubs on the local level. By I9IO, the G.F.W.C. boasted a membership of over two million. ${ }^{13}$ Far from being a feminist organization, the G.F.W.C. was highly conservative in its ideals and orientation. In the words of an early Federation historian, "conservation in its best and highest sense" was the "raison d'être" of the organization. ${ }^{14}$ Even the suffrage movement-middle-of-the-road and respectable by this period ${ }^{15}$ - was thought to be too controversial to embrace. Women, it was felt, could better influence legislators without votes or party affiliation, since their motives could not be questioned. ${ }^{16}$ The leaders of the G.F.W.C., themselves always more "progressive" than the rank and file, refrained from endorsing the suffrage campaign until the very eve of victory. ${ }^{17}$

Local New Jersey clubs were imbued with these same noncontroversial ideals of self-perfection and service, and formed a state federation with ties to the national governing body in November I 894. ${ }^{18} \mathrm{~A}$ "profound" commitment to education was central to the N.J.S.F.W.C. from the start, but it was not until I 9 I I that the Federation decided to pool its efforts with those of like-minded women, members of the Federation or not, and "local public-spirited men"19 who might be interested in the cause of higher education for women within the state.

The movement in New Jersey received a decided boost when Mrs. Mabel Smith Douglass, President of the College Club of Jersey City, assumed leadership of the Federation's campaign. A Barnard graduate herself, she was an inveterate worker whose dedication to the cause of higher education for women continued until her death in 1933. Born in Jersey City in I 877 of old Dutch colonial stock, she was the wife of

${ }^{13}$ William H. Chafe, The American Woman: Her Changing Social, Economic, and Political Roles, 1920-1970 (New York: Oxford University Press, 1972), p. I6.

${ }^{14}$ Mary I. Wood, The History of the General Federation of Women's Clubs (Norwood, Mass.: Norwood Press, ig12), p. 3 (2.

15 Kraditor, pp. 2 I I-2 I 2.

16 Banner, p. 90.

17 O'Neill, p. 259.

${ }^{18}$ On the establishment of the N.J.S.F.W.C., see Jennie Cunningham Croly, The History of the Woman's Club Movement in America (New York: Henry G. Allen and Co., 1898), pp. 825-852; also, Ada D. Fuller, "A History of the New Jersey State Federation of Women's Clubs," pamphlet, I917, RC-MSD, Box II, folder 18, I 9 .

${ }^{19}$ Bulletin published by the Woman's College Committee of N.J.S.F.W.C., Feb.-Mar., 19 15, RC-MSD, Box II, folder 17 . 
William Shipman Douglass, the owner of a wholesale produce business, and the mother of two children. Properly bred, well-educated, and financially secure, she was also graced with influential political friends, among them her Jersey City neighbor, James T. Fielder, the Governor of New Jersey. Eminently respectable, she seemed the proper person to lead the Federation's fight, and to broach the subject of higher education for women to the Rutgers Trustees.

The Trustees did show an early cautious interest in the plan, and Mrs. Douglass found three strong supporters in Drury W. Cooper, James Neilson, and Leonor F. Loree. That the Trustees found Mrs. Douglass to be "reasonable and intelligent" was directly related both to her personal respectability and to the conservative nature of the college which she proposed to them.

Early on, the women of the Federation had recognized that the endowment of a totally separate women's college with private funds would be financially unfeasible. In this, they were following the lead of concurrent movements in Delaware, Virginia, Georgia, and South Carolina to establish colleges for women in some way affiliated with an existing male college or institution. ${ }^{21}$ Not only was this the most financially expedient line of attack, but the fact that Mrs. Douglass was herself a Barnard graduate also endeared her to the idea of a coordinate college. Barnard, founded in $\mathrm{I} 879$, was itself a compromise institution, since coeducation was not acceptable to the Columbia Trustees.

Rutgers, from the start, seemed the logical college with which to affiliate, due to its status as the recipient of both federal and state funds. Affiliation with Stevens was never even considered, and Princeton was known to be opposed due to its disappointing try at a female annex, Evelyn College, in the r89os. What was significant, however, in the early deliberations with the Rutgers Trustees was the fact that coeducation was never mentioned by Mrs. Douglass and the N.J.S.F.W.C. The women of the Federation were quick to assure the Trustees of old Rutgers that they had nothing of the sort in mind. All agreed that co-

\footnotetext{
${ }^{20}$ Senator Joseph Frelinghuysen to Rutgers President W.H.S. Demarest, Mar. 26 , I 9 I4, President's Papers, Rutgers University Archives.

${ }^{21}$ By 1914 , bills for the establishment of affliated women's colleges were in progress at the University of Virginia, the University of Delaware, the University of the South at Sewanee, and the State University of South Carolina; see RC-MSD, Box II, folder Io, I4: MSD correspondence with officials of the Connecticut College for Women, and the proponents of a women's college to be affiliated with the University of Virginia, I 9 I4; Box II, folder II: MSD correspondence with officials of the Women's College of Delaware, 1914; and Box II, folder 16 : statistics on coordinate and neighboring women's colleges, I 914 .
} 
education served to foster "unpleasant" social relations: not only was it a source of "distraction" to both professors and students, but it also led to "unnatural" and "unhealthy" competition between the sexes. ${ }^{22}$

Furthermore, the colonial, classical tradition of Rutgers, the eighth oldest college in the nation, made its Trustees fiercely unwilling to remodel their venerable institution along Western coeducational lines. Mrs. Douglass must be lauded for her political savvy in that she recognized early on the tactics that had to be used. In a period when women lacked political power, it behooved them not to threaten unnecessarily the males who were ultimately to decide upon the college's final authorization. "This project must under no circumstances be called coeducation," Mrs. Douglass warned the Federation, "as that term would certainly draw forth opposition among the friends of Rutgers." Writing to President Demarest of Rutgers, she adopted a reassuring tone: "As to coeducation-I would not worry about that--no one wants it, neither the parents of the girls nor the parents of the boys . . I know that I would lose some of my best backers were I to propose coeducation." ${ }^{\text {"2 }}$

The N.J.S.F.W.C. echoed Mrs. Douglass in this respect. "The horror of a coeducational college," proclaimed a speaker at the Federation's I 9 I 2 convention, "was most repellent to all." 4 The women of the Federation clung to respectability as fiercely as they shunned militancy, and their success was directly attributable both to the mild-mannered tone of their approach and to their conservative and limited vision of why New Jersey women needed the benefits of a college education.

The middle and upper middle class membership of the N.J.S.F.W.C. embodied the concept of what has been called "social feminism" in such a way as to pose the least challenge to a male dominated authority structure. While not necessarily opposed to the movement for women's rights, they simply gave priority to other broader - and milder-movements of social reform. The motto of the organization, "Perfect good fellowship united with practical work, ${ }^{\mathbf{2} 6}$ not only reflected its middle class emphasis on utility, but announced itself as blandly apolitical. Al-

22 See Mrs. Douglass' personally compiled bibliography on the social effects of coeducational colleges, RC-MSD, Box II, folder 12.

${ }^{23}$ Minutes, Jersey City College Club, Oct. 25, 1912; MSD to W.H.S. Demarest, July 24, I9I3, President's Papers, Rutgers University Archives; W.H.S. Demarest, "A zoth Century College," address broadcast over radio WOR, Apr. 18, 1933, published N.J.C. Bulletin nr. ${ }_{5}$ (July, $x_{933}$ ), NJC-ana.

${ }^{24}$ Mrs. William T. Ropes, President, N.J.S.F.W.C., 1913-1915, "The Faith which Removed Mountains," The N.J. Chubwoman: New Jersey College for Women Number, XV (1940), 8; NJSFWC-SB.

25 The concept of "social feminism" was first used and developed by O'Neill, p. x.

${ }^{26}$ Fuller, p. 7, RC-MSD, Box II, folder I8, 19. 
though the college fight grew up in New Jersey at the exact time that four different groups were pushing for a state-wide referendum to be held on the woman suffrage question, ${ }^{27}$ the state Federation barred all discussion of suffrage in its meetings. As if in a direct challenge to state suffragists, Mrs. William T. Ropes, President of the state Federation, issued a plea to members to cease whatever other activity in which they might be engaged and devote total effort to the cause of the state college for women. ${ }^{28}$ The organization as a body remained frankly noncommittal on the suffrage issue, although prominent state suffragists and "antis" both were members of the Federation. As a matter of policy, however, the farthest the Federation would go was to endorse the idea that the suffrage question should be submitted to the voters. ${ }^{29}$

Although the New Jersey state suffrage referendum of October, I 9 I 5 went down to defeat by a $58 \%$ majority, the college movement gained momentum in the same period. Editorial support for the cause of the college was overwhelming. The Trenton Times bluntly remarked, "As between votes for women and higher education for them, the college movement should win." the two concurrent women's movements-suffrage and higher education -was a direct result of the narrow and non-threatening vocational language in which female educational demands were couched.

Teaching was from the first identified as a proper vocation for the college-educated woman. Since a college degree was required to teach in the high schools of the state, it was argued that New Jersey should provide the means for its female citizens to attend college within its borders. Not only was the cost of attending an out-of-state institution prohibitive to all but a select few, but "only the strongest girls" could withstand the physical rigors of commuting daily to nearby institutions like Barnard. The proposed college was so closely identified with teaching in the public mind that an editor of the New York Sun naively remarked that New Jersey "should long ago have had a teachers' college or a women's college, which is the same thing." ${ }^{32}$

An initially too exclusive emphasis on preparation for careers in sec-

${ }^{27}$ On the history of the woman suffrage movement in New Jersey, see Elizabeth Cady Stanton and Ida Husted Harper, eds., The History of Woman Suffrage (New York: J. J. Little and Ives Co., 1922), VI, 412-433.

${ }^{28}$ MSD, "Early History," p. Ir.

29 "Want More Women Active in Civil Life," Elizabeth Daily Journal, Oct. 27 , igr3; O'Neill, pp. 86-87; Banner, p. 90; and Wood, p. 265.

30 "A College for Women," Trenton Times, Dec. 5, 1913.

31 Scoon, p. 6.

32 "The Need for Women's College in Jersey," New York Sun, Dec. 27, Igr4. 
ondary education almost backfired on the movement's supporters. If women needed a college simply because of flaws in the certification policy of the State Board of Education, then a simple solution to the problem, suggested Dr. James M. Green, principal of the state normal school in Trenton and foremost opponent of the move to link a women's college with Rutgers, would be to expand the normal school system so that the mandated college degree could be awarded. All that really was necessary was to convert the state normal school at Trenton into a state teachers' college, and then the women's needs would be satisfied. ${ }^{33}$ Dr. Green's arguments revealed a blatantly anti-feminist bias. Obviously ignoring his own advanced degrees, he coyly argued that women really had no need of such accoutrements: "There has been alot (sic) of the worshipping of degrees as a fetish, but, really, is the degree or the knowledge the important thing? "34

Other male educators were also wary of supporting the college movement until they could be assured of its limited scope. H. W. Dutch, principal of the Montclair Public Schools, wrote to Mrs. Douglass:

I believe that such an institution would be immediately successful if it would be itself primarily a technical college for women; that is, if it could offer to the girls of the state opportunity to prepare themselves for librarian, secretarial, nursing, domestic science and art, physical training, and social and civic betterment work. ${ }^{35}$

Obviously, Mr. Dutch was really saying that he could support the college if he could be assured that its graduates would be immediately channeled into proper and respectable female roles.

While Mrs. Douglass and the women of the Federation were united in their opposition to the Green proposal, they were actually in substantial agreement with the vocational arguments put forth by $\mathrm{Mr}$. Dutch. Although Mrs. Douglass recognized that women did not "wish to be fitted for the profession of teaching to the exclusion of other vocations, "36 the professions for which the college founders sought to

${ }^{33}$ For the pros and cons of the normal school conversion argument, see "Trenton Wants Woman's College," Home News, New Brunswick, Nov. 20, rgi4; K. C. Babcock, Dean of the College of Liberal Arts and Sciences, University of Illinois, to MSD, Jan. 9, 19I5, RC-MSD, Box II, folder I7; for MSD's reflections on the matter, see her handwritten notes, RC-MSD, Box II, folder i 7 .

34 "Is There Really Need for a Woman's College at Rutgers?" Trenton Sunday Times Advertiser, Mar. 8, 1914.

${ }^{35} \mathrm{H}$. W. Dutch to MSD, Apr. 9, 1914, RC-MSD, Box II, folder $x 2$.

${ }^{36}$ MSD, notes opposing the normal school conversion plan, RC-MSD, Box II, folder 17 . 
fit women were equally deserving of being labelled "typically feminine."

It can be argued that public opinion supported the movement because the college's proponents, in their official rhetoric, never appeared to challenge traditional views of acceptable sex roles. Not only could college-educated women become teachers, they noted, but they could also hold such "new and exciting" positions as "court stenographers and private secretaries." The modern world demanded efficiency, and the college-educated woman, judged Mrs. Douglass, was first and foremost an efficient woman: "There are many high paying positions awaiting the efficient woman, but she must be a college woman, with broad education plus stenography and typewriting." Elsewhere Mrs. Douglass enumerated at length the kinds of jobs for which college women were particularly well-suited. College trained women were qualified to become:

... managers of homes and institutions, inspectors of food supplies, expert buyers of fabrics, designers, assistants in research work, students of home economics and homemakers, caretakers of children and trained workers in charity.

Even those women who might aspire to more daring pursuits could be expected to approach them from a distinctively feminine angle. "If there were more women architects," Mrs. Douglass predicted, "we would have more closets and better arranged kitchens." ${ }^{37}$

The founders' emphasis on vocationalism was a direct result of their assessment of the clientele to whom the new college would appeal. From its conception, N.J.C. was envisioned as a college for the "girl of small means," who could not afford to travel outside the state for her college education. ${ }^{38}$ Official pronouncements of the movement's backers continually reiterated that colleges like Vassar and Bryn Mawr should not feel threatened by the proposed institution, since the type of girls destined, both financially and socially, for institutions of that sort would still find their way there: "It is likely that few if any of the girls who would go to a traditional college, e.g. Bryn Mawr, Vassar, would go to N.J.C., for most of the young women who want the sort of training

37 "Free College Course for Your Girl?", NJSFWC-SB; "New Brunswick Teachers' Club Banquet at Hotel Klein and Hear Inspiring Speeches," Home News, New Brunswick, Nov. 8, 1913; "Makes Strong Plea for Woman's Dept. at State College," Hudson Dispatch, Dec. I I, I 913 ; and "Hoyt Alumni Luncheon Notable for Good Cheer," Home News, New Brunswick, Nov. I9, 1914.

${ }^{38}$ MSD address at New Jersey State Teachers' Assn. Convention, Atlantic City, N.J., Dec., 1914, RC-MSD, Box II, folder I7. 
given by these institutions will not be influenced away from them by the founders of a new institution." 39

Class considerations colored the founders' thinking from the outset. Although they themselves were products of classical educations, they knew that their mythical "girl of small means" must be suited for some sort of remunerative work after college and before marriage. They were equally aware that parents of such girls might also need to be motivated to incur the expense of sending their daughters to college by the promise of future financial rewards. Essentially then, the careerism advocated at N.J.C. was not an aggressive one of female swashbuckling through male preserves, but a vocationalism pure and simple, arising more from a practical recognition of the financial needs of the students than from any notions of ideological feminism.

It was hoped, however, that the college could also meet the needs of a second kind of girl, one who did not have to "earn her living by teaching or some kind of secretarial work" ${ }^{* 0}$ after college. Yet, the education which the founders envisioned for this second "class" of girl was also patently non-feminist. She was to be provided with a "good general education" together with-and this was always emphasized-a training that would fit her to be an "efficient housekeeper." A1 Again and again in official college rhetoric one finds the familiar dichotomy: woman is destined to be both citizen and homemaker, and "for both of these major functions the times require the most extended education possible." As citizens, the students of the new college were urged to develop an interest in economic and social problems not so that they might become lawyers and politicians themselves, but in the hope that their study of the social sciences might "lead them into some form of community service after college." As homemakers, women had a "natural aptitude for housecleaning" which could be channeled, through education, into community and charitable work. The home, agreed the college's backers, had had its functions expanded to the outside world, “. . . so in the industrial and social fields women are finding their work again, and new forms of training are needed to fit them for it." ${ }^{{ }_{42}}$

${ }^{39}$ Scoon, p. 7. $\quad{ }^{40}$ Ibid., p. $12 . \quad 41$ Ibid.

${ }^{42}$ Dr. Dorothy Waldo, "Why Educate Women?" and Lillian Gardner, "The College and the Federation-Shared Interests and a Shared Philosophy," The N.J. Clubwoman: New Jersey College for Women Number, XV (1 940) ; Mrs. M. Casewell Heine, President, N.J.S.F.W.C., I929-1932, "The Federation and the College," NJSFWC-SB; " 'Wisconsin Idea' To Be Duplicated," Philadelphia Record, Nov. 22, 19 13; "Women's College for Jersey," New York Post, May 16, 1914. 
Clothed in such language, all the fire was taken out of the originally egalitarian, proto-feminist arguments on which the initial cries for female higher education in New Jersey had been based. Like suffrage ideology itself, the ideology behind the movement for N.J.C. had moved from an argument from justice to one from expediency. ${ }^{43}$

The crowning factor in the mobilization of public opinion behind the college campaign was the argument that higher education for women would enable them to be better mothers. The view that it was each woman's sacred destiny to be a mother was enshrined in N.J.S.F.W.C. publicity. The women of the state were urged to join the movement behind N.J.C. in the interests of "their daughters and their race." Appeals for money and support were addressed to "every woman who realizes that in the little girl we have the potential mother of the race, and that the level to which the future of the race will attain depends also upon the same little girl." ${ }^{\prime 4}$ Such rhetoric was particularly appealing to the press. Editorials were pleased to announce, along with their support, the fact that the "right-minded" women behind N.J.C. certainly knew their place:

No one knows any better than the right-minded women who have fought this fight for a woman's college that woman's duty and her greatest glory is to be the childbearer of the race. Nothing is so sacred to a woman as that strong purpose of her being. . . . Give woman the weapons and she will fight desperately anything and everything that seeks to come between her and her greatest privilege. ${ }^{45}$

Education, the New York Post's editorial went on to say, was one of those "weapons" which would enable women to become "more efficient ... and better wives and mothers."

Significantly enough, it was actually a "typically feminine" preserve -home economics-which was ultimately the key to the creation of the New Jersey College for Women. In 1917, Congress supplemented the I 862 Morrill Act, which had created the nation's land grant colleges, with the Smith-Hughes Bill, which appropriated federal money to all state universities and state-aided colleges for the teaching of agricultural

43 "Arguments from expediency" for woman suffrage were all those which claimed society would somehow benefit from the enfranchisement of women; see Kraditor, p. 58. 44 "Free College Course for Your Girl:", NJSFWC-SB; "Woman's College in New Brunswick," Metuchen Recorder, Jan. 9, I9 5.

45 "Woman's College of New Jersey," New York Post, Apr. I3, I918. 
trades and home economics. Rutgers, as the land grant college of New Jersey, was then in the legally mandated position to finance at least one full four-year collegiate course for women, a teacher training course in home economics. This development, plus the availability of an attractive property, the John Neilson Carpender estate overlooking the Raritan River, one-and-one-quarter miles from Rutgers, were the critical factors which finally made possible the opening of the new college. The Rutgers Trustees took a three year lease on the Carpender property with an option to buy, and in April, I918, passed a resolution "to establish a Woman's College as a department of the state university of New Jersey." ${ }^{\text {"46 }}$ The new college opened its doors on September I9, 1918, seven years after the women of the N.J.S.F.W.C. had first mounted their campaign.

Although the establishment of N.J.C. was actually tied to these two fortuitous events of 1917-1918, the passage of the Smith-Hughes Bill and the availability of the Carpender estate, the cautious, conservative, respectable ideology of the founders was critical in the mobilization of public opinion behind the cause of a women's college. The narrow vocationalism which they advocated was perceived as decidedly non-threatening, especially when compared to concurrent suffragist rhetoric. Businessmen rallied around the cause of N.J.C. because they recognized the financial advantages that were certain to accrue both to them and to the municipality lucky enough to have the college established within its confines. ${ }^{47}$ The state's politicians were also quick to get into the act. "It is better to have 20,000 women with us and not against us," remarked New Jersey's Senator Joseph Frelinghuysen. ${ }^{48}$ The Rutgers Trustees were in agreement that a coordinate college "would not be so bad" provided that the institution could raise its own funds and not expect Rutgers to assume any financial obligations. ${ }^{49}$ Thus, the fund-

${ }_{46}$ Trustees' Minutes, Apr. 12, 1918 , Rutgers University Archives.

${ }^{47}$ In a 1914 survey, it was found that there were 853 New Jersey women then attending college out of state, thus depriving the state's economy of approximately onehalf million dollars. See "Will City Have College for Women?" Home News, New Brunswick, Jan. 15, I915; for business reactions to N.J.C., see "Logical Place for Women's College," Home News, New Brunswick, Jan. I6, 1915; and Fred R. Cutcheon to MSD, Mar. 31, 19I4, RC-MSD, Box II, folder I 2.

${ }^{48}$ Senator Joseph Frelinghuysen to Rutgers President W.H.S. Demarest, Feb. I6, 19 18, President's Papers, Rutgers University Archives.

${ }^{49}$ Frelinghuysen to Demarest, Mar. 26, 1914, President's Papers, Rutgers University Archives. 
raising efforts of the women of the N.J.S.F.W.C. were crucial to the college's establishment.

To call attention to the non-liberating quality of the college which the women of the Federation created is not to deny, question, or impugn the sincerity of their motives. The women of the N.J.S.F.W.C. continue to give generous support to "their" college, renamed Douglass College in 1955 as a fitting tribute to the efforts of its greatest benefactor and first Dean. ${ }^{50}$

Yet, in seeking to explain the death of American feminism after I920, the fight for N.J.C. is illustrative of wider trends in American society that presaged that death. Lack of political radicalism in the suffrage movement itself was paralleled by a corresponding lack of careeroriented radicalism in the vision of these educators. Middle class women demanded both the vote and higher education as ends in themselves, as further evidence of what middle class respectability and status were all about. The educated woman was told that she could be of service to her children and to her community, but not specifically to herself. A far-reaching conviction of what woman could and should become was not only what was most lacking in these educators' goals, but also what would have been most decisive to the continued success of American feminism.

${ }^{50}$ The New Brunswick Home News, as early as Jan., I9I5, had suggested naming the proposed college "Douglass College," "in honor of the woman whose work has stamped her as pre-eminently worthy of this recognition." 